\title{
Work-life balance among seafarers of international cruises
}

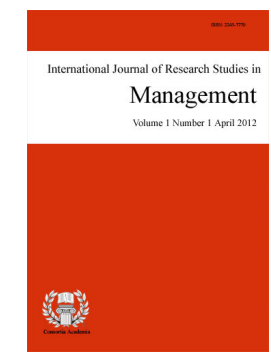

\section{Abstract}

This paper assessed the work-life balance of seafarers in the International Cruises. It presented the demographic profile of seafarers; their work-life in terms of emotion, behavior, demand, as well as their work-life conflict, family management, work-life control, work-life initiatives; the significant difference when grouped according to the profile variables; and most importantly it proposed reinforcement mechanisms for quality of work-life based on the result of the study. The study used descriptive method of research, adapted questionnaire, and various statistical tools. The researcher presented the result and come up with conclusions that majority of the respondents were aged 31 to 40 years old, female, single, college graduate and worked for about 1 to 10 years. Based on the result on the degree of work-life balance of onboard seafarers gave so much emphasis on how the company respect their work-life balance and its personal demands; good salary and benefits; satisfaction on the number of working hours; high demand from family which interfere their work; sending their children's care or school; balance between work and family; and company initiatives for employees' family care benefits. For the recommendations: the cruise ship company may provide some provisions on benefits extending to the immediate family or parents of the crew members; will be more lenient to hire the crew member with light health issues and give special attention on the workload and fatigue issues of the crew members.

Keywords: work-life balance; seafarers; international cruises; work-life conflict; family management 


\section{Work-life balance among seafarers of international cruises}

\section{Introduction}

A job is not just work but life as well for dedicated and committed workers. What happens to work has a great impact to their personal life and vice-versa. For them, to work is to live. Since work and life definitely have direct relationship, one area which has been necessary in the field of business, academic and research were work-life balance is essential. In today's situation, work-life balance becomes significant and focal point of the interest among people in the academic, business, political and social levels (Devi \& Rani, 2013; Koubova \& Buchko, 2013). The necessity for work-life equilibrium is the result coming from the reactions of the individuals who happens to experience work-family conflict versus work-life, this may occur once personal role becomes unsatisfying as to what is being perceived and expected (Ruppanner, 2013).

Generally, those people who go to work have the mind-set that things will turn out desirable and productive once they go home. Work will not be an issue at home and vice versa. This comes true also with their belief that they still have a social life once they are outside their work area. However, this is never true for those who work in the ship industry. In contrast, there are cases in the organization invades one's social life. Undeniably, to be employed on cruise ships extremely demand longer working hours. It is always beyond eight hours. The onboard crew has lesser time for themselves to deal their family bonding and social life.

Work-life balance is when wok-to-life is being achieved and enjoyed at the same time. This is something not common to everyone rather it depends on one's preferences and lifestyle (Work-Life Balance, 2018). Working in a cruise ship is tiresome, being tied to an occupation that accompanied with so many things to dealt with like for instance; boredom, fear of rough seas, anxiety of being away with family, sea sickness, and among others. Behind those impressive salary and benefits there are many aspects of life of seafarers are being sacrificed and set aside. The kind of occupation of onboard crew is highly profound with many detriments or impairments. The life at the sea is isolated and limited most of the time. Being at the middle of the sea would mean inaccessible to many things to perform his role as maybe a father or a mother or a son or daughter and the like. The only thing that could consolidate their feelings, finding time to be with their loved ones through phone calls, chatting or video calls. In that way the quality of life will lead to such purposes of being a family provider. Sometimes onboard workers would accept that at least they have a work-life balance. It served the purpose of being away and worked at the middle of the sea is to guarantee they have something to provide for their family.

Filipinos, known for their engagement in overseas employment, are included in those groups of people who dominate the cruise ships workforce. In fact, being employed as seafarer has been the most enticing of all. Not only because of the fact that manning agencies are required by law to automatically remit to the seafarers' family left in the Philippines, but also because this kind of work does not discriminate workers in terms of educational qualification. Even a College undergraduate can land a job in the sea just by complying with the required training and specialization usually facilitated by the company or the agency. In terms of career growth for officers, this industry has a lot of opportunities to offer so that with determination and efficient work knowledge and performance, promotion is within reach. In terms of compensation, the minimum compensation of sea-based workers is far more than the minimum pay of those who are land-based. With all the reasons cited, along with other benefits, it is no wonder that a lot of Filipinos have been willing to be a part of this thriving industry (Terry, 2013).

Three reasons have motivated the researcher to work in this study. First, the scarcity of research conducted in the cruise ships has made the researcher to focus his paper on such topic since he is aware of the pressing need to assess the current conditions of the sea workers so that necessary changes or improvement be made. Second, the researcher, after having worked in a cruise line for few years, recognizes the need for evaluating the 
effectiveness of work-life balance programs implemented by the company. Third, with the launching of Star Cruises' "Jewels of the South China Sea" in Manila in 2017, marking the first-ever homeport deployment of Superstar Virgo in the Philippines, there is a great certainty that a lot more Filipinos would be employed in cruise ships, does check and balance have to be in place.

This study focuses on measuring the effectiveness of the work-life balance programs implemented by the identified cruise ships in the Philippines such as Princess Cruises, Aida Cruises, Viking Cruises, P \& O Cruises UK, P \& O Cruises Australia, Saga Cruises, Crystal Cruises, Mopas Cruises, Star Cruises, and Costa Cruises. The result of the study may provide the companies with information on what and how to improve their programs. Also, it may provide other companies with a systematic means of assessing the services company has for its workers. The government may also benefit from the study since the result may provide them with important information that may have an impact on the implementation of laws related to labor and overseas work.

\subsection{Objectives of the study}

The study assessed the work-life Balance of seafarers in the International Cruises. Specifically, it achieved the following: (1) presented the demographic profile of seafarers in terms of age, gender, civil status, educational attainment and length of service in the company; (2) determined the degree of work-life balance in terms of: emotion, behavior, demand, (3) assessed the degree of work-life balance in terms of: work-life conflict, family management, work-life control, work-life initiatives; and (4) proposed reinforcement mechanisms for quality of work-life based on the result of the study.

\section{Methods}

The researcher used the descriptive research design to accomplish this study. Descriptive research is a type of research used to describe the data and the test hypothesis of the current status of the subject of the study, the researcher chose this method of research to help explain the information and determine the attributes of quality of work-life long among seafarers. The respondents of this study were 305 seafarers who are currently working in the selected international cruise ships. They were determined using Slovins formula at five percent margin of error employing stratified random sampling.

The main data gathering instrument used was adapted from the study of Luansing (2016). The first part refers to the demographic profile of the respondents in terms of age, gender, civil status, educational attainment and length of service in the company; the second, determines the degree of work-life balance in terms of: emotion, behavior, demand; third, assesses the degree of work-life balance in terms of: work-life conflict, family management, work-life control, work-life initiatives.

The researcher used the following statistical tools in the analysis of data: frequency count, simple percentage, weighted mean, independent $t$-test, and One-way Analysis of Variance (ANOVA). Frequency count/Percentage these was applied to determine the demographic profile of the respondents. Weighted arithmetic mean - this was applied to determine the seafarers' positive reinforcement in their workplace and the assessment of the respondents' quality of work-life. Independent $t$-test - this determined the differences on the responses of seafarers on the assessment of quality work-life. One-way analysis of variance - this were calculated to determine the significant difference between the profile variables in their workplace.

In adherence to the ethical considerations, and to observe the confidentiality of the surveys, no specific names of establishments and respondents were asked in the study. Equally, the distinctiveness of the respondents was protected. No personal opinion was given by the researchers, only information and results based on the data gathered. More so, the results or findings of the study were well taken care of and assured the safekeeping of the information gathered. Full consent from the respondents with high respect was obtained before continuing with the study. Hence, there is a guarantee in the protection of the privacy of the research study. 


\section{Results and discussion}

\section{Table 1}

Percentage distribution of the respondents' profile

\begin{tabular}{|c|c|c|}
\hline Profile Variables & Frequency & Percentage $(\%)$ \\
\hline \multicolumn{3}{|l|}{ Age } \\
\hline 21-30 years old & 86 & 28.20 \\
\hline $31-40$ years old & 124 & 40.70 \\
\hline $41-50$ years old & 78 & 25.60 \\
\hline 51 years old and above & 17 & 5.60 \\
\hline \multicolumn{3}{|l|}{ Sex } \\
\hline Female & 270 & 88.50 \\
\hline Male & 35 & 11.50 \\
\hline \multicolumn{3}{|l|}{ Civil Status } \\
\hline Single & 215 & 70.50 \\
\hline Married & 75 & 24.60 \\
\hline Separated & 14 & 4.60 \\
\hline Widowed/widower & 1 & .30 \\
\hline \multicolumn{3}{|l|}{ Educational Attainment } \\
\hline Undergraduate & 20 & 6.60 \\
\hline College Graduate & 278 & 91.10 \\
\hline Other & 7 & 2.30 \\
\hline \multicolumn{3}{|c|}{ Length of stay in the company } \\
\hline $1-10$ years & 276 & 90.50 \\
\hline $11-20$ years & 29 & 9.50 \\
\hline
\end{tabular}

Table 1 presents the percentage distribution of the respondents' profile wherein most of the participants were at the age of 31 to 40; there were 124 or 40.70 percent followed by aged 21-30 with 86 or 28.20 percent; next is 41-50 years old with 78 or 25.60 percent and finally, aged 51 years old and above with 17 or 5.60 percent from the total number of respondents. The majority of the on-board crew were at the aged 30's. They have been part of the cruising industry for several years. They go back on board one after another contract, they belong to 50's. These individuals are in their retiring period. Some of them are on the process of preparing themselves to make a new phase of their lives together with families for good or may be some time to relax from a year of working on board. In terms of sex, majority of the respondents were female with 270 or 88.50 percent while, male got 35 or 11.50 percent. These female respondents are part of food and beverage department on board if not they are housekeeper. While male is at lounge or kitchen section.

In terms of civil status, most were single with 215 or 70.50 percent; married were 75 or 24.60 percent; the separated, got 14 or 4.60 percent and the last widowed/widower, 1 or .30 percent. Since majority of these respondents are the early 30's, they are still single, looking ahead to fulfill their dreams and make use of their time to collect work experiences, preparing themselves for greater opportunities in the industry. Moreover, in terms of educational attainment of the respondents, majority of them were college graduate with 278 or 91.10 percent while, the undergraduate got 20 or 6.60 percent and others were 7 or 2.30 percent. Today's industry requires candidates for jobs with a minimum educational requirement of at least college degree compared from long years ago that accepts high school graduate. The previous relevant work background was the most privileged or advantaged to fill in the position onboard. The last profile of the respondents; their length of stay in the company; majority of them were 276 or 90.50 stayed for about 1-10 years while the least 29 or 9.50 percent of the respondents stayed 11-20 years. This reveals that most of the respondents have worked in cruising for less than 10 years. They became part of the industry after having their 1-2 years land-based experience. Meanwhile, relative to the result in terms of age; the older the respondents, the longer they have worked as an on-board seafarer. This research provides the data that describes the composition of the respondents such as age, sex, education and the like. These demographic data will help the researcher to understand the perceptions and preferences of the participants. The importance of demographic files contributes to research system for statistics, 
Work-life balance among seafarers of international cruises

predictions and aid in development resulting to social outcomes (Lake, 2016).

\section{Table 2}

Degree of work-life balance in terms of emotions

\begin{tabular}{lccc}
\multicolumn{1}{c}{ Indicators } & WM & VI & $\mathrm{R}$ \\
\hline 1. I have peace of mind at work even if I have unfulfilled family obligation & 3.84 & Strongly Agree & 2 \\
2. I have confidence in my job. & 3.44 & Agree & 11 \\
3. I have a good work-life balance & 3.60 & Strongly Agree & 6 \\
4. I have peace of mind about my job even when I am at home. & 3.00 & Agree & 14 \\
5. I get personal satisfaction while doing my job. & 3.33 & Agree & 13 \\
6. I feel like I am contributing on the success of the organization & 3.35 & Agree & 12 \\
7. I feel that my work and life are balanced in this job. & 3.49 & Agree & 9 \\
8. I find it easy to concentrate at work because of my family support. & 3.46 & Agree & 10 \\
9. I feel my organization respects my desire to balance my work and & 3.99 & Strongly Agree & 1 \\
personal demands. & & & \\
10. I feel relaxed and calm even if I have requirements to be submitted to the & 3.58 & Strongly Agree & 7 \\
Superior & & & \\
11. The management, heads and Superior are my role models & 3.62 & Strongly Agree & 5 \\
12. I feel I am very productive in my job & 3.63 & Strongly Agree & 3.5 \\
13. I am proud to work for my organization & 3.63 & Strongly Agree & 3.5 \\
14. My Superior understands me when I have to put my personal or family & 3.56 & Strongly Agree & 8 \\
life first. & & & Strongly Agree
\end{tabular}

Legend: 3.50 - 4.00 = Strongly Agree; 2.50 - 3.49 = Agree; 1.50 - 2.49 = Disagree; 1.00 - 1.49 = Strongly Disagree.

Table 2 shows the degree of work-life balance in terms of emotions with a composite mean of 3.54 verbally interpreted as "strongly agree"., As a human being, the state of being is relevant to the emotion. It may affect work output and performance in an organization. Crew members with happy and positive feelings are effective in their work while stressed or sad or burnout affect the quality of work. Therefore, emotions and quality of work are important to the success in the workplace. Emotion plays a significant role of crew members on board to balance their work duties along with family life even in a daily basis. The implications of emotion to the organizations increased consistent effects on the job functions (Applewhite, 2017).

The indicators strongly agreed by the respondents include they felt that their organization respect their desire to balance their work and personal demands (3.99). The respondents believed that they have work-life balance since their company implement board intercession program which has a positive effect on their work-life. One of the amenities enjoyed by the respondents are the communication satellite and internet satellite as well which gave them a chance to contact their families while onboard. So at least, they could be able to maintain stronger family and spousal relationship while away from home. Among the seafarers' communication is significantly considered decreasing the tension and stress of being far away with their wives and their children (Theotokas et al., 2015). Also, their kind of work is indispensable. Therefore, these offshore crew members deserve to be respected and value their importance in the industry (Raunek, 2019a).

Crew members have peace of mind at work even if they have unfulfilled family obligations (3.84). The respondents still have peace of mind even many of the family events were missed to attend as they are ones who shouldered the expenses like birthdays, anniversary and graduations and among others. One of the important influencing factors considered by many seafarers to stay in their job is their high wage payments and career promotion opportunities that able to sustain their family (Consolidated Training Systems Incorporated (CTSI) Admin, 2015) even though there are certain aspect of being a member of the family remains unfulfilled. There are other cases, despite of their high wage still not enough to acquire a property resulting to engage in loan or mortgage liabilities.

Furthermore, they are very productive and proud in their job (3.63). The respondents are self-fulfilled with their job. Having a job in cruise makes them support their family more than enough to have a decent life. They 
can afford to bring or send their children to good school's university as well. There are several factors that may affect the productivity of the on-board crew members which include work exposure to psychosocial hazards, cultural differences, language barriers and face the consequences of boredom and loneliness (Sharp Minds Content, 2017).

However, among the least as agreed by respondents the contribution on the success of the organization (3.35); personal satisfaction while doing the job (3.33) and peace of mind about their job even when they are at home (3.00). It was found out that crew members are feeling secured with their job even if they go back home. Job security is identified through their job contract which addressed to job continuity. However, there are some cases when coming back to work is not easy sometimes it took them couple of months or more. The possible reasons that hindered them to renew their job contract is due to health problem and poor performance evaluation. Having a job security and satisfaction provides them with peace of mind to heighten their intention to stay in their job (Oa et al., 2018).

\section{Table 3}

Degree of work-life balance in terms of behavior

\begin{tabular}{|c|c|c|c|}
\hline Indicators & WM & VI & $\mathrm{R}$ \\
\hline 1. I am enthusiastic about my work & 3.58 & Strongly Agree & 7.5 \\
\hline 2. I am productive in my job & 3.58 & Strongly Agree & 7.5 \\
\hline 3. I have no problem in shifting behavior from my work with each day & 3.30 & Agree & 13 \\
\hline $\begin{array}{l}\text { 4. My Superior understands when I talk about personal of family issues } \\
\text { that affect my work. }\end{array}$ & 3.60 & Strongly Agree & 4.5 \\
\hline $\begin{array}{l}\text { 5. I believe that the high expectations of my Superior motivate me in } \\
\text { fulfilling my work and personal responsibilities? }\end{array}$ & 3.60 & Strongly Agree & 4.5 \\
\hline $\begin{array}{l}\text { 6. My Superior extend resources to help me with my family } \\
\text { responsibilities? }\end{array}$ & 3.59 & Strongly Agree & 6 \\
\hline $\begin{array}{l}\text { 7. My workplace organizes team-building activities that promote positive } \\
\text { working relationship and camaraderie. }\end{array}$ & 3.56 & Strongly Agree & 9 \\
\hline $\begin{array}{l}\text { 8. My workplace organizes extra-curricular activities, such as sports } \\
\text { tournament, musical contest, health and wellness programs and the like. }\end{array}$ & 3.41 & Agree & 12 \\
\hline $\begin{array}{l}\text { 9. The Management offers opportunities to grow, enhance my skills and } \\
\text { develop my capabilities }\end{array}$ & 3.46 & Agree & 10 \\
\hline 10. I believe I have a secure job with this organization even in the future. & 3.45 & Agree & 11 \\
\hline 11. I have good salary and benefits in our company & 3.87 & Strongly Agree & 1 \\
\hline $\begin{array}{l}\text { 12. My Superior shows appreciation in every well-done contribution job I } \\
\text { make }\end{array}$ & 3.62 & Strongly Agree & 3 \\
\hline 13. My working environment enables me to do my job-effectively & 3.63 & Strongly Agree & 2 \\
\hline Composite Mean & 3.56 & Strongly Agree & \\
\hline
\end{tabular}

Table 3 reveals the degree of work-life balance in terms of behavior with a composite mean of 3.56 as strongly agreed by the respondents. Majority of the respondents strongly agreed that they received good salary and benefits in their company (3.87). Being a crew member is a promising job to which they earn high paid salary and received good benefits like travel incentives for the immediate family. Also, they are able to send their children in good school provide their family with good life and fulfill their dreams of having their house, car and other properties. Further, good performance evaluation gives the privilege to recommend relatives and friends. Remuneration and the promise of high wages is a factor that affects the behavior of the crew members to join the seafaring profession as well as to remain in it. This reason significantly influences the behavior of the employees (Theotokas et al., 2015). Also, these international shipping companies have well defined provident fund system, offered attractive higher salary and benefits and good working environment (Kaushik, 2019).

Next, their working environment enables them to do their job effectively (3.63). Respondents shared some stories of their humble beginnings before they were finally hired for the job. They experienced series of trainings relevant to the position assigned to them. At first, things are not easy; they need to be skillful and have good attitude towards their work. Once they go onboard, they are well trained to do their job effectively. Aside from 
Work-life balance among seafarers of international cruises

the work area is perfectly good and pleasant, good relationship with co-workers and able to adjust with other nationalities are also important. Improving the working conditions will increase the retention rate of the seafarers on board while; decrease the stress at work (Applewhite, 2017). Moreover, their superior appreciated their contribution to their job (3.62). The respondents are very proud of whoever they are. They are happy that they are valued and appreciated in the workplace. Their foreign superiors acknowledged their contribution at work. There are some instances that they received an award of recognition. The crew member received several incentives like free helicopter tour, train ride, and travel incentives or jewelries every time they obtained good performance record. These indicators though they are not highly favored by the respondent's standout positively, the respondents believed that they have secured job in the organization even in the future (3.45); on the side of having extra-curricular activities their workplace abled to organize sports tournaments, musical contest, health and wellness program and the like (3.41); lastly, the respondents did not encounter problem in shifting behavior from the work with each day (3.30). It is very clear even before they started with their job that they are going to have a shifting duty. It is always being told during the job orientation. They are pre-conditioned about their working environment once they are onboard. Once onboard, there is always the possibility to render extra hour or work without pay or no day off or work two shifts if it is needed or happens during turn around day. No matter how tiring and time demanding for seafarers, the work must go on and they have to work positively. Offshore workers typically have work in rotational schedules, that they work for a specified number hours, of days/weeks and do not work for typical shorter period of time.

\section{Table 4}

Degree of work-life balance in terms of demands

\begin{tabular}{|c|c|c|c|}
\hline Indicators & WM & VI & $\mathrm{R}$ \\
\hline 1. I am satisfied with the number of hours I work & 3.71 & Strongly Agree & 1 \\
\hline 2. I can meet the requirements of my job without working long hours & 3.70 & Strongly Agree & 2 \\
\hline 3. My family time does not suffer as a result of my working long hours & 3.55 & Strongly Agree & 9 \\
\hline $\begin{array}{l}\text { 4. My workplace provides technological resources that allow me to work } \\
\text { from home if I have family affairs to attend to. }\end{array}$ & 3.59 & Strongly Agree & 8 \\
\hline 5. I could arrange to work part-time in my current job if I wanted to & 3.60 & Strongly Agree & 6 \\
\hline 6. I can attend to my family needs even if I have a long hour on my job & 3.60 & Strongly Agree & 7 \\
\hline 7. I can schedule my preferred leave of absence supported by my Superior. & 3.50 & Strongly Agree & 11 \\
\hline 8. I do not need to spend extra hour at work just to finish my workload. & 3.18 & Agree & 12 \\
\hline $\begin{array}{l}\text { 9. I find myself spending more time on work related projects rather on } \\
\text { personal endeavors }\end{array}$ & 3.63 & Strongly Agree & 4 \\
\hline $\begin{array}{l}\text { 10. I was able to spend my weekends with my family and my social life } \\
\text { without worrying about my job responsibility }\end{array}$ & 3.10 & Agree & 13 \\
\hline $\begin{array}{l}\text { 11. Despite the number of hours spent in work I am still able to go out and } \\
\text { have my social life. }\end{array}$ & 3.63 & Strongly Agree & 4 \\
\hline $\begin{array}{l}\text { 12. When needed, I am willing to put extra effort to work and get my job } \\
\text { done. }\end{array}$ & 3.10 & Agree & 13 \\
\hline 13. Flexible number of hours is allowed in my workplace & 3.63 & Strongly Agree & 4 \\
\hline 14. We are allowed to offset for the overtime we worked instead of paying us. & 3.51 & Strongly Agree & 10 \\
\hline Composite Mean & 3.50 & Strongly Agree & \\
\hline
\end{tabular}

Table 4 as presented the degree of work-like balance in terms of demands with a composite mean of 3.50 and strongly agree as verbally interpreted. With the highest mean among the rest of the indicators have shown strong agreement from the respondents as revealed that they were able to satisfy the number of hours they have worked (3.71). Such instance is very precise because most of the time, it goes beyond. They usually work eleven (11) hours or more in a day as needed. Most of the respondents agreed that working onboard rendered flexible duty hours. Excessive workload accompanied with so much physical demands and complexity of the work makes the crew members became impatient to their work. Furthermore, the respondents strongly agreed that their jobs met the requirements even without working long hours (3.70). Work onboard is very demanding, flexibility and patience are essential while performing the task. For crew members, there is no such long or short working hour because number of guests are consistent every day. They are expected to work until the guests 
need their services. Additional high job demands added to that the complexity of the work greatly affected their physical and mental conditions of the crew members in today's age cruising companies were being managed by minimum crews (Edward \& Rothband, 2015).

Another, the following are equally assumed positively by the respondents that they were able to find themselves spending more time on work related projects rather on personal endeavors and despite of the number of hours of work they still able to go out and have a social life and they were given a flexible number of hours in the workplace (3.63). All respondents agreed that they experienced to work more than the expected number of working hours and it is their priority over their personal agenda. However, there are many chances that come along their way that they can be able to spend time for themselves and socializing with others. Specially, they still have time to communicate with their family across boarders over the phone call or video call. The offshore crew members are reliant on the communications satellite, as well the flexibility of their schedules, so to make time to communicate with their families back home. Other indicators may not be that strong favored but still agreed by the respondents where their schedules are based on their preferred leave of absence supported by their superior (3.50). They do not spend extra hours at work just to finish the workload (3.18) and the least where the respondents were able to spend weekend with their family and have a social life without worrying about their job responsibility, they are also willing to put an extra effort to work and get the job done (3.10). The life of crew members while onboard includes spending their weekend only happened over phone calls or via skype or video call. It is not the typical way of having weekend bonding with their families. While onboard, they can also perform their work and have communication with their family during their free hours. For on board crew members, doing communications with their families at home associated with their non-work roles; reduces anxiety among them. It can be argued giving them psychologically performing even away from home thereby creating higher levels of work-to-home segmentation (Benito-Osorio, 2014).

\section{Table 5}

Degree of work-life balance in terms of work-life conflict

\begin{tabular}{|c|c|c|c|}
\hline Indicators & WM & VI & $\mathrm{R}$ \\
\hline 1. The demands of my work interfere with my home and family life. & 3.56 & Strongly Agree & 3 \\
\hline $\begin{array}{l}\text { 2. Because of my job, I can't involve myself as much as I would like in } \\
\text { maintaining close relations with my family spouse/partner. }\end{array}$ & 3.32 & Agree & 4 \\
\hline $\begin{array}{l}\text { 3. Things I want to do at home do not get done because of the demands my } \\
\text { job puts on me. }\end{array}$ & 3.04 & Agree & 8 \\
\hline 4. I often have to miss important family activities because of my job. & 3.17 & Agree & 6 \\
\hline $\begin{array}{l}\text { 5. There is a conflict between my job and the commitments and } \\
\text { responsibilities I have to my family or spouse/partner. }\end{array}$ & 3.61 & Strongly Agree & 2 \\
\hline $\begin{array}{l}\text { 6. The demands of my family or spouse/partner interfere with work related } \\
\text { activities. }\end{array}$ & 3.74 & Strongly Agree & 1 \\
\hline 7. I sometimes have to miss so that family responsibilities are met. & 3.15 & Agree & 7 \\
\hline $\begin{array}{l}\text { 8. Things I want to do at work don't get done because of demands of } \\
\text { family or spouse/partner. }\end{array}$ & 2.89 & Agree & 9 \\
\hline $\begin{array}{l}\text { 9. My home life interferes with my responsibilities at work such as getting } \\
\text { on time, accomplishing daily tasks and working overtime. }\end{array}$ & 3.20 & Agree & 5 \\
\hline Composite Mean & 3.30 & Agree & \\
\hline
\end{tabular}

Legend: $3.50-4.00=$ Strongly Agree; 2.50 - 3.49 = Agree; 1.50 - 2.49 = Disagree; 1.00 - 1.49= Strongly Disagree.

Table 5 shows the degree of work-life balance in terms of work life conflict with a composite mean of 3.30, verbally interpreted "agree". Performing two important responsibilities and obligations between work and family are not easy to balance. There are times one suffered for some inconvenience or conflicting matters. This really requires intelligent time management to balance and avoid the conflicting matters. Work life conflicts suggest unfavorable impression on the adaptation and satisfaction of offshore and seafarers' families, separation anxiety to family member absence and lessen the quality of marital relationship when conflict gone through a lot (Slišković \& Penezic, 2015).

The highest mean pertains to the demands of their family or spouse / partner interfering with their 
Work-life balance among seafarers of international cruises

work-related activities (3.74); this is inevitable that many of the crew members just like ordinary people experienced some family issues which most of the time affects their job performance. Some specific reasons when one family member has a health problem or accident, or their beneficiaries engaged in early marriage or addiction and so many to mention. The bottom line has the same effect to the seafarer they became inefficient because they cannot focus on their job. Another conflict occurs is between their job and commitments and responsibilities to the family or spouse/partner (3.61), The crew members find conflict since most of the time they are away from their family; they missed a lot of relevant family matters that supposed to be they are the ones to be there. But it is impossible for them since they are living miles away from their family. Sometimes, this cannot be compensated even they are providing much of the financial side for their family. This situation makes them incapacitated to completely perform their responsibilities to their family. One cannot stay focused at work when crew members are bothered by family or personal issues. Seafarers facing family problems while at shore will directly hit and affect the focus on duties. It is extremely difficult for them to handle their work when they are physically on board but mentally back home in their family (Raunek, 2019b).

Furthermore, the demand of their work which is interfered by their home and family life (3.56). In this case, performing the responsibility to family affects to fulfill the work effectively. According to the respondents, many of them leave their job and look for a land-based job so to be with their family physically most of the time or to be hands on to some important matters that really requires full attention. Others tend to venture into business like rented apartment and restaurants. As the crew members pursue their career on board, they are able to balance it while their good family relationship living miles away. On the other hand, based on the results that respondents sometimes have to miss the job so to meet their family responsibilities (3.15). It also happened that there are things they want to do at home, but they do not get them done because of the demand of their job (3.04) or the other way around; there are things at work they don't get it done because of the demand coming from the family or spouse / partner (2.89). There are many instances, according to the respondents, that they neglect or had a lesser their attention to fulfill their job because they fell into such a problematic situation. They cannot work because of some stressful cases happening in their family. Specifically, when someone dies in the family; as much as they wanted to go home right away, they could not do that immediately because they are at the middle of the sea. Majority of the offshore crew members get torn apart every time they leave their family so to live far away, missing precious moments with their loved ones and parenthood. The seafarers miss so much time spending to their wives; children growing old without him being around is a painful feeling (Raunek, 2019b).

\section{Table 6}

Degree of work-life balance in terms of family management

\begin{tabular}{lccc}
\hline \multicolumn{1}{c}{ Indicators } & WM & VI & $\mathrm{R}$ \\
\hline 1. I can make alternate childcare arrangements when necessary & 2.89 & Agree & 7 \\
2. I can make of my children to or from a childcare setting or school. & 3.13 & Agree & 1 \\
3. I can go to school events for my children. & 2.94 & Agree & 5 \\
4. I can stay at home with my sick child. & 3.10 & Agree & 2 \\
5. I can take my children for health care appointments. & 3.01 & Agree & 3 \\
6. I can be home when my children get home from school. & 2.99 & Agree & 4 \\
7. I can spend fun or educational time with my family & 2.90 & Agree & 6 \\
& Composite Mean & 2.99 & Agree \\
\hline
\end{tabular}

Legend: $3.50-4.00=$ Strongly Agree; 2.50 - 3.49 = Agree; 1.50 - 2.49 = Disagree; 1.00 - 1.49 = Strongly Disagree .

Table 6 exposes the degree of work-life balance in terms of family management with a composite mean of (2.99) positively interpreted as agree. Being a crew member, according them, gives them the opportunity to be a good provider to their family. The respondents are able to give better life to their children or elevate the status of their family. The offshore crew member, while on board is dedicated to providing all the finances for the family; the loved ones facilitate the smooth domestic functioning. The communication now comes in and begin to realize the importance to sustain the relationship of each member of the family. With the advent of internet on ships, text/video chat, email exchange, instant messaging tools and other such mediums, experience togetherness while being far from home (Bansal, 2010). With the highest mean are the following: the respondents can make their 
children to or from a childcare setting or school (3.13), the respondents are capable to pay child facility or nanny to take care of their children. The seafarers are accountable for the welfare of the family especially their children to be able send it schools and do the best to keep things going in the best possible way. Finding happiness for freedom on decision-making and acting responsibly for the families are great self-fulfillment for them.

On the other hand, they can stay at home with their sick child (3.10). The respondents if it is really necessary are allowed to be with their family to take care of the sick. They can file emergency leave so to spend some time with sick family member. Once done with their problem they can go back to work and finish their contract. One of the worst thing's seafarers have to face at sea is the news of an unfortunate event or emergencies that has happened back home. Considering the life of seafarers with an emergency back home. Unfortunately, at sea, nobody is going to arrange for the ship to be diverted from the middle of the ocean or evacuate using by a helicopter. Such diversions are done only in Medical Emergencies happened within the ship. Further, most seafarers will, at some point of time in their tenure, feel that they've made the biggest mistake of their lives by choosing a career at sea. It leads to breakdowns and to negative thoughts or it could be due to the demanding schedule of the vessel that leaves no time for anything other than work. Even missing family members and feeling homesick can bring out such feelings.

Moreover, they take their children for health care appointments (3.01); though the respondent is not physically present with their children, the financial side of supporting the family is done. Whereas with least mean were at the respondents can go to school events for their children (2.94), they spend fun or educational time with their family (2.90) and can make alternate childcare arrangements when necessary (2.89); the respondents can easily make childcare arrangements since they afford to pay for the expenses. Their capability on the financial side could compensate or lighten the burden their problems specifically on childcare. The family of the crew member planned and kept control to take care of the needs within the time frame while the family member is working on board and earning money to support all the expenses (Bansal, 2010).

\section{Table 7}

Degree of work-life balance in terms of work-life control

\begin{tabular}{|c|c|c|c|}
\hline Indicators & WM & VI & $\mathrm{R}$ \\
\hline $\begin{array}{l}\text { 1. In general, I can control over the way I balance working, family responsibilities and } \\
\text { other interests in my life. }\end{array}$ & 3.23 & Agree & 1 \\
\hline 2. I have choice when I take vacations or days off. & 3.16 & Agree & 2 \\
\hline 3. I have choice over when I begin and end each workday or each work week. & 3.07 & Agree & 5.5 \\
\hline 4. In general, I have control over the way I balance working and parenting. & 2.95 & Agree & 8 \\
\hline 5. I have choice in obtaining adult supervision for my child before or after school. & 3.07 & Agree & 5.5 \\
\hline int and quality of care available for a sick child. & 2.97 & Agree & 7 \\
\hline 7. I have choice in making unanticipated child-care arrangements & 3.09 & Agree & 4 \\
\hline 8. I have choice over the amount and quality of day care available for a dependent & 3.12 & Agree & 3 \\
\hline
\end{tabular}
parent or other relatives.

Legend: $3.50-4.00=$ Strongly Agree; $2.50-3.49=$ Agree; $1.50-2.49=$ Disagree; $1.00-1.49=$ Strongly Disagree

Table 7 shows the result of degree of work-life balance in terms of work-life control with a composite mean of 3.08 as verbally interpreted as agree. According to the respondents, their company has good benefits that favored much of their family concern. There are several provisions that allow them to support their family in many ways. Like for instance, the ship has communication facility that the crew members onboard were given the opportunities and time to communicate with their families. The cruising company improved the organizational culture and self-efficacy, identified for the crew members that generally affect the quality of work-life offshore. Hence, the organizational support found to be had an indirect effect through self-efficacy and perceived fatigue of many seafarers (Kim \& Jang, 2018).

The most agreed indicators of the respondents, they can control over the way they balance their work, family responsibilities and other interests in their lives (3.23). There are cases that controllable and can have 
other options to at least they can still perform their family responsibilities. To be specific, even if their child / children will spend their birthday, maybe they are physically absent, but they could be able to provide abundant or grand celebration. In many cases, families of crew members encountered difficulties adjusting to characteristics of seafaring occupation. To many seafarers, separation to their family is one of the stressors that caused them to hardly manage balancing their work and family matters. It affects the enthusiasm towards work because they are pre-occupied about the family matters.

Also, they have a choice when to take their vacations and day offs (3.16), Part of the employees' policy is giving the crew members their vacations and day off. However, there are instances that cancellation of day offs, or vacation happened when there is a shortage in the workforce. If that would be the case, the crew will receive additional appropriate compensation based on the rendered hours as stated in their employee's manual. A seafarer must be granted a compensatory rest period in case he/she is required to be on call during rest hours. A number of ships working hours and hours of rest for crew members in all positions must be displayed in a place of easy accessibility for purpose of informing the seafarers in due time. Master can suspend the schedule of work hours and hours of rest in situations of vessels distress and require a seafarer to perform necessary duties until normal conditions are restored.

Further, when they have a choice over the amount and quality today care available for their dependent parent or other relatives (3.12); after their contract or before rendering the new contract, the crew members were given ample time to spend quality bonding with their friends, relatives and families during the vacationing crew. , the least were agreed to have a choice over to begin and end each workday or each work week and when they chose in obtaining adult supervision for their child/children before and after school (5.50), Also, to choose over the amount and quality of care available for a sick child (2.97) and the last, to have control over the way they balance working and parenting at same time (2.95). The respondents stated that even if they are living far away from their children at the end of the day, they are still parents. The distance is not an excuse or a barrier to perform the role of being the parents. Some of them have told that through open communication with their children, they are able to give parental guidance. The crew member offshore is still able to sustain child support as their parents they still have the capability even though they far away to do certain things as parenting with enough and open communication to the family (Oa et al., 2018).

\section{Table 8}

Degree of work-life balance in terms of work-life balance initiatives

\begin{tabular}{|c|c|c|c|}
\hline Indicators & WM & VI & $\mathrm{R}$ \\
\hline 1. Ensuring people take their annual leave regularly. & 3.42 & Agree & 3 \\
\hline 2. Providing an info and referral service to assist with care of aged parents. & 3.48 & Agree & 1 \\
\hline 3. Providing assistance with childcare costs (i.e., salary sacrificing). & 3.36 & Agree & 6 \\
\hline 4. Providing more flexible work hours. & 3.00 & Agree & 8 \\
\hline 5. Providing a fitness program (e.g., paying for sports club membership). & 3.08 & Agree & 7 \\
\hline 6. Allowing for special family leave, eg to care for a sick dependent. & 2.96 & Agree & 9 \\
\hline 7. Providing vacation care for children during school holidays. & 3.40 & Agree & 5 \\
\hline 8. Offering temporary part-time work options during family crises. & 3.47 & Agree & 2 \\
\hline 9. Providing scholarships for employees' children & 3.41 & Agree & 4 \\
\hline Composite Mean & 3.29 & Agree & \\
\hline
\end{tabular}

Legend: 3.50 - 4.00 = Strongly Agree; 2.50 - 3.49 = Agree; 1.50 - 2.49 = Disagree; 1.00 - 1.49 = Strongly Disagree.

Table 8 indicates the degree of work-life balance in terms of work-life balance initiatives with a composite mean of 3.29 with verbal interpretation of agree. Luckily, many of the cruising companies are good in providing employees benefits and policies, including facilities and amenities. The work-life balance initiatives are coming from the organization or company. This refers to the programs provided to the employees based on the diverse needs arising from the employees. These initiatives are somehow increasing the employee's behavioral outcome positively and satisfying work performance. The respondents highly agreed that they were provided with information and referral service to assist their aged parents (3.48); parents and immediate family are covered by the insurance. This is stated in the employee's manual if company has a provision on that matter. This is included 
and being discussed during the employee's orientation. The dependents of the seafarers are filed as the beneficiaries. The parents and immediate family are sustained based on the term stated in the health care policy of the company (Oa et al., 2018).

It was followed by them were being offered with temporary part-time work options during family crisis (3.47); other could have extra job like hairstylist, join in entertainment department and crew shows, kitchen helper or replace someone if it is needed during the turn-around day. There are some who have been there themselves, but for others - the whole institutionalized nature can make them question whether seafarers can adapt to an office ashore. Now of course there are issues with transitioning - the reality of life at sea is hard, but there are plusses too. There are often tax-free salaries, and there time off far outstrips anything ashore (Crewtoo n.d).

Last is ensuring their people to take their annual leave regularly (3.42); the annual leave is the vacation right after 6 to 8 job contracts of the crew members. Seafarers shall be entitled to paid annual leave of a minimum of two and a half (2.5) days for each month (or 30 days) of employment on board ship, this shall include all travelling time to and from the vessel. For periods of employment of less than one month, the seafarers leave entitlement. This is also stated in the articles released by International Labor Organization (ILO). The main reason for the discomfort of many seafarer is when they get disconnected from his mainstream earning life as soon as he goes on leave or is done with his contract.

The least indicators of work-life balance initiatives agreed by the respondents; they are being provided with fitness program (3.08), flexible work hours (3.00) and are allowed to have a special family leave (2.96). The respondents were provided with travel incentives based on their good, evaluated performance. This is another form of employees benefits as they work onboard. The crew were given an ample to time to travel depending on the specified schedule of the cruise. Under the Maritime Labor Convention (MLC) 2006 (2014), the annual leave with pay is calculated on the basis of 2.5 days for every calendar month of employment. This is a minimum entitlement and if the employment agreement or the collective bargaining agreement provides for a higher rate of paid annual leave, then this higher rate is applicable.

\section{Table 9}

Proposed reinforcement mechanisms for quality of work-life based on the result of the study

\begin{tabular}{lll}
\hline \multicolumn{1}{c}{ KRA/Objectives } & \multicolumn{1}{c}{ Strategies/Program } & \multicolumn{1}{c}{ Outcomes } \\
\hline $\begin{array}{l}\text { Work-life conflict } \\
\text { demands of family or } \\
\text { spouse/partner }\end{array}$ & $\begin{array}{l}\text { Modify workload by decreasing the } \\
\text { quantity of work hours, increase quality } \\
\text { work hours }\end{array}$ & $\begin{array}{l}\text { Jobs become more fulfilling } \\
\text { while dealing with their } \\
\text { family's responsibilities at the } \\
\text { same time }\end{array}$ \\
$\begin{array}{l}\text { Family Management } \\
\text { To construct a program for } \\
\text { childcare arrangements when } \\
\text { necessary }\end{array}$ & $\begin{array}{l}\text { Increase benefits to crew members by } \\
\text { providing a provident fund, medical } \\
\text { insurance for the } \\
\text { family and paid vacation }\end{array}$ & $\begin{array}{l}\text { Increased employees } \\
\text { retention }\end{array}$ \\
$\begin{array}{l}\text { Work-life Control } \\
\text { To balance working and } \\
\text { parenting }\end{array}$ & $\begin{array}{l}\text { Improve organizational goal } \\
\text { by promoting work engagement: }\end{array}$ & $\begin{array}{l}\text { Form good work team } \\
\text { Valuing opinions }\end{array}$ \\
$\begin{array}{l}\text { Fair treatment } \\
\text { Create family-oriented goals }\end{array}$ & High spirited crew members \\
& $\begin{array}{l}\text { Enjoyed their work while } \\
\text { fulfilling the responsibility to } \\
\text { their family }\end{array}$ \\
$\begin{array}{l}\text { To amend provisions for } \\
\text { Special family, leave i.e., to } \\
\text { care for a sick dependent }\end{array}$ & $\begin{array}{l}\text { members by valuing their need for } \\
\text { work/life balance through providing timely } \\
\text { relief, and shore leave }\end{array}$ & $\begin{array}{l}\text { Reinforced the work-life } \\
\text { balance of the crew members } \\
\text { on board }\end{array}$ \\
\hline
\end{tabular}




\section{Conclusion and recommendation}

Majority of the respondents are aged 31 to 40 years old, female, single, college graduate and worked for about 1 to 10 years. Based on the result on the degree of work-life balance of onboard seafarers, much emphasis was given on how the company respects their work-life balance and its personal demands; good salary and benefits; satisfaction on the number of working hours; high demand from family which interferes their work; sending their children's care or school; balance between work and family; and company initiatives for employees' family care benefits. There is a significant difference of responses on the degree of work-life balance specifically on demand among the respondents' aged 41 to 50- and 51-years old seafarers on emotions. However, the single seafarers have higher assessment on their work-life conflict and work-life control compared to married individuals. The researcher is able to propose a program for work-life balance of onboard seafarers.

The cruise ship company may provide some provisions on benefits extending to the immediate family or parents of the crew members. Insurance may be covered by their insurance policy even during vacation or no matter how long it was as long as the crew is still connected to the company. Also allowing crew members to continue the payment scheme for their immediate family may be considered. The company may be more lenient to hire the crew member with light health issues. The cruising company may give special attention on the workload and fatigue issues of the crew members by considering the supply of additional crew on board and modify long hours of duty. Proposed Reinforcement Mechanisms for Quality of Work-Life may be implemented to promote work-life-balance. And finally, the future researchers may conduct similar study using different variables specifically on effectiveness of work organization and family, social and work engagement while on board.

\section{References}

Applewhite, P. (2017). Examining the role of emotional intelligence in the work and life balance of foster care workers. https://scholarworks.waldenu.edu/

Bansal, I. (2010). Seafarer's wife: 8 best practices to manage family and self when he is at sea. https://www.marineinsight.com/

Benito-Osorio, D. (2014). The impact of family and work-life balance policies on the performance of Spanish listed companies. Management, 17(1), 214-236. https://doi.org/10.3917/mana.174.0214

Consolidated Training Systems Incorporated (CTSI) Admin. (2015). Seafarers are contented with their life at the sea: Manpower report 2015. http://ctsi.com.ph/

Crewtoo. (n. d.). Make the most of your career ashore (Tips for seafarers). http://www.crewtoo.com/

Devi, C., \& Rani, S. (2013). The concept of conflict and balance relationship between work-life conflict and work-life balance. International Conference on Technology and Business Management.

Edwards, J. R., \& Rothbard, N. P. (2015). Mechanisms linking work and family: Clarifying the relationship between work and family constructs. Academy of Management Review, 25, 178-99. https://doi.org/10.5465/amr.2000.2791609

Kim, J., \& Jang, J. (2018). Seafarers' quality of life: Organizational culture, self-efficacy, and perceived fatigue. International Journal Environment Res Public Health, 15(10), 2150. https://doi.org/10.3390/ijerph15102150

Koubova, V., \& Buchko, A. (2013). Life-work balance. Management Research Review, 36(7), 700-719. https://doi.org/10.1108/MRR-05-2012-0115

Lake, M. (2016). What is the importance of demographic study? https://www.quora.com/

Maritime Labour Convention 2006. (2014). Right to leave. http://seafarersrights.org/

Oa, O., Ho, F., Obianuju, A., \& Demilade, F. (2018). Work-life balance initiative as a predictor of employ. Academy of Strategic Management Journal, 17(1). Retrieved from https://www.abacademies.org/articles/worklife-balance-initiative-as-a-predictor-of-employees-behaviou ral-outcomes-6923.html 
Evangelista, S.

Raunek. (2019a). 10 reasons you must thank seafarers. https://www.marineinsight.com/

Raunek. (2019b). 12 main reasons seafarers quit sea jobs. https://www.marineinsight.com

Ruppanner, L. (2013). Conflict between work and family: An investigation of four policy measures. Social Indicators Research, 106(1) 327-347. https://doi.org/10.1007/s11205-011-9933-3

Sharp Minds Content. (2017). Improving seafarers' productivity, welfare. https://www.manilatimes.net/

Slišković, A., \& Penezic, V. (2015). Occupational stressors, risks and health in the seafaring population. Review of Psychology, 22(1-2). https://doi.org/10.21465/rp0022.0004

Terry, W. (2013). The perfect worker: discursive makings of Filipinos in the workplace hierarchy of the globalized cruise industry. Social \& Cultural Geography, 15(1), 73-93. https://doi.org/10.1080/14649365.2013.864781

Theotokas, L., Papachristou, A. A., \& Stantchev, D. (2015). The role of communication to the retention of seafarers in the profession. WMU Journal of Maritime Affairs, 14, 159-176.

https://doi.org/10.1007/s13437-015-0085-1

Work-life balance. (2018). Work-life balance defined. https://worklifebalance.com/ 